\title{
Nexus Between Industrial Policies and Entrepreneurial Development in North Eastern Region of Nigeria
}

\author{
${ }^{1}$ Joshua Dzankar Zoaka \& ${ }^{2}$ Waglati Ornan \\ ${ }^{1,2}$ Department of Economics, Adamawa State Polytechnic, Yola, Adamawa State, Nigeria
}

\begin{abstract}
Industrial policies has been viewed as one of the fundamental and the most significant factor in promoting the development of entrepreneurship in any economy. Therefore, this study is aimed at achieving the nexus between industrial policies and entrepreneurial development in Nigeria, with emphasis on some selected north eastern part of the country which consist of Adamawa state, Gombe state and Taraba state. Using a primary source of generating data and chi square, distributive and percentages methods of analysis were employed among others. From the findings however implies that there is positive response from quite number of respondent that some of the government industrial policies aid at improving entrepreneurial activities in the region if proper implementation is considered. The policy implications of the study suggests that the current industrial policies plays an important role in creating a modern way of setting up a standard business and there is greater motivation towards effectiveness on the recent industrial policies within the region
\end{abstract}

Keywords:- Industrial policy, Entrepreneurship development, Chi square, Nigeria.

\section{INTRODUCTION}

The Government by its actions or failure to act also does influence both the economic and non-economic factors for entrepreneurship. Any interested Government in economic development can help through its clearly expressed industrial policy; promote entrepreneurship in one way or other. By enacting favorable industrial policies Government can create a facilitative set up to establish enterprises by the entrepreneurs. From a quite number of recommended literatures, progress in technology empowered by innovative initiative, research development, human capital investment were determine by long term economic growth and industrial policies (Pradhan et al., 2020). With this the existence of large literature indicating that the entrepreneurial culture is very paramount for forming a vivacious economic atmosphere that encourages capital availability, networks, creative gift and some other sources to limb economic growth and innovation. Some number of research work have discussed the relationship among entrepreneurship, national innovation and impact on factors of production (Schwab \& Zhang 2019).

Industrial policies are sector-specific, unlike broader macroeconomic policies. Examples of the latter, which are horizontal, economy wide policies, are tightening credit and taxing capital gains, while examples of industrial policy, which involves vertical, sector-specific policies, include protecting textiles from imports and subsidizing export industries. Industrial policies are interventionist measures typical of mixed economy countries (Lucchese et al., 2016 and Draper, T. 2017).

Thus, the prime objectives of this paper is to assess the nexus between government's industrial policies on the Development of Entrepreneurship in the North Eastern part of Nigeria. Other specific objectives are:

$>$ To examine the effect of current industrial policies on entrepreneurship in Nigeria.

$>$ To evaluate the perception of entrepreneurs on Government policies.

$>$ To assess the various forms of industrial policies applied in Nigeria.

$>$ To identify the measures that will ensure formulation and implementation of good industrial policies in Nigeria.

Research hypothesis has been drawn in order to test the outcomes of the findings. Therefore two null and alternative hypothesis is presented below in accordance with the work of (Chienwattanasook \& Jermsittiparsert., 2019):

$H_{0}$ : There is a significant effect on the current industrial policies towards entrepreneurship development

$H_{1}$ : There is a no significant effect on the current industrial policies towards entrepreneurship development

$H_{0}$ : There is positive perception on the consistencies of government policies towards entrepreneurship development $H_{1}$ : There is negative perception on the consistencies of government policies towards entrepreneurship development

This research work is novel and will improve the existing literature thereby collaborating the government industrial policy and entrepreneurial development within the sampled states. Furthermore, we assessed the comparable variation of current industrial policies and the entrepreneur's perceptions on the policies developed by government agencies within the region, using the sampled of about three hundred responded sourced from the field. Chi-square, histogram, percentage and pie chart were applied in order to present outcomes of the study, which work in conformity with the work developed by (Chienwattanasook \& Jermsittiparsert., 2019 and Nasiripoor, 2013). 
The motivation of this current study is based on the points outline above and the articulated views observed from the review of the literature, also in accordance with points figure out from table 1 and 2 . However, none of the research to the best of the author's knowledge has considered the inference between government's industrial policies on the development of entrepreneurship in the sampled region and as well using a primary sources of data.

The remainder of the paper is outlined as follows: Section two gives an overview of the literature that was reviewed; Section three contains the data description and methodology; section four is presentation and discussion of the empirical results; and section five provides the conclusion and policy inference.

\section{AN OVERVIEW OF THE RELATED LITERATURE}

This chapter reviews the relevant literature on assessing the nexus of government Industrial Policies on the development of Entrepreneurship in Nigeria; with emphasis to three selected state in the North East region of Nigeria. This chapter reviews literature related to the definition and concept of entrepreneur and entrepreneurship; objectives of entrepreneurship development; economic growth and entrepreneurship development in Nigeria and industrial policies.

According to Blackburn (2016) entrepreneurship is considered in worldwide scenario as one of the motivating factor towards economic growth and development, in this regards governments create several programs related to entrepreneurship to increase and promote potential and existing entrepreneurs. example, in Nigeria during the regime of former president Goodlock Jonathan organize an initiatives for both potential and current entrepreneurs known as YOUWIN, Barack Obama in United states of America (USA) setup an America initiative, United Kingdom (UK) the loan scheme was developed for young entrepreneurs in UK, for Mexico Becate entrepreneurial program was also setup in Mexico and that of India is called National Rural Employment Guarantee Act etc., all these demonstrates some part of the government effort in different regions and countries to encourage positive perception of individual job creation and self-employment. Ndofirepi, (2016) in their own view opine that a steady increase in the number of self-employment within the UK region, occurs based on the lifestyle that is family aspect, job satisfaction, cultural background etc.

\section{Government effort in developing entrepreneurship in Nigeria}

The effort made by Nigerian government towards establishing several enterprise such as the small and medium enterprise (SMEs) which begins from the period of 1961 with the formation of the first Industrial Development Centre (IDC) in the eastern part of Nigeria, Owerri, Imo state. The focus on SMEs establishment is based on the fact that it is a key factor and engine for growth of any economy particularly developing economies.
Sequel to this, government objective in the economic recovery process especially during the periods of 1999 to 2015 has taken bold steps towards initiating and implementing a number of policy measures, these programs include; YOUWIN initiatives by Goodluck Jonathan, World Bank SMEs 1 and 2 Loan Scheme, National Economic Reconstruction Fund (NERFUND), Peoples and Community Bank, Nigerian Bank of Commerce and Industry (NBCI), Export Processing Zone (EPZ), Manufacture In-Board Scheme (MIBS), National Poverty Eradication Program (NAPEP), Advisory Agencies, National Directorate of employment (NDE), Small and Medium Enterprises Developing Agency of Nigeria (SMEDAN) Family Economic Advancement Program (FEAP) (Onukwuli 2014; Mary et al., 2015)

\section{> The impact of Industrial Policies in Nigeria}

As this research recognizes industrial sector as the heartbeat of economic development and a child of necessity, Nigeria immediately after independence considered it wise to reposition the sector for economic development through policies. Hence the importance and relevance of industrialization cannot be overemphasized there is every need for us to unmask and explain lucidly the various industrial policies and strategies embarked upon by Nigeria. Import-Substitution Industrialization Policy (ISI, 1960's), The Nigerian Indigenization Policy (1972), Structural Adjustment Programme (SAP 1986), Trade and Financial Liberalization Policy (1989), Bank of Industry (BOI, 2000), Small and Medium Industries Equity Investment Scheme (SMIEIS, 2000) (Adenipekun., 2013).

\section{METHODOLOGY AND COLLECTION OF DATA}

This section deals with the method adopted in carrying out the study, the targeted population and the particular sample required from the population. From this current study, the population was some of the prospective and current entrepreneurs from the selected states of the north eastern parts of Nigeria. A cluster sample technique was adopted for the collection of sample in this region. Which is also in line with the techniques employed by (Yaghmaei \& Ghasemi, 2015), first total population was estimated, secondly the size of the population sample. A sample of 300 respondents were drawn for analysis. Furthermore, structural questionnaire were used for the collection of data. In the aspect of methodological approach, several equation and chi-square analysis technic is adopted. And is explained by the formula below:

$$
\text { Chi-square }\left(X^{2}\right): \quad X^{2}=\sum \frac{(o-e)^{2}}{e}
$$

Where: $\chi^{2}=$ chi-square

$\mathrm{E}=$ expected frequency

$\mathrm{O}=$ observed frequency

$\sum=$ symbol of summation 


\section{PRESENTATION OF RESULTS AND ANALYSIS}

This part provide an overview of the major findings generated from the outcomes of the questionnaire. Noted clearly that all the items from the results are presented in a good and presentable way, where no validity problem within the items that were selected for the equation used. The results were presented on figures and tables showing the demographic and the response of the respondents respectively.

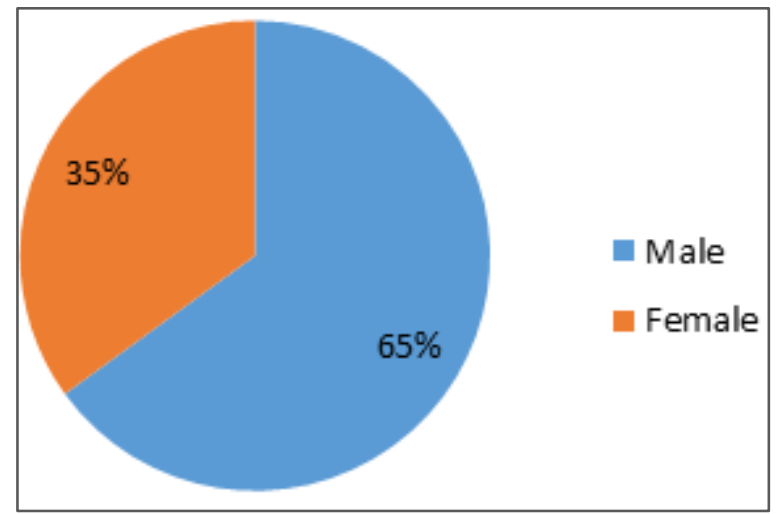

Fig 1:- Shows Gender distribution of Adamawa State under study Source: field survey, 2020

From figure one above the gender distribution for the case of Adamawa State respondents shows that majority of the respondents were male with about 65 percent and female having 35 percent, this indicates that more of the prospective and current entrepreneurs were men in Adamawa state. This support the argument of Molina, J., (2020) and Kakouris et al., (2016) that more men are involved in the business than women and there is a need for government to develop a program to encourage female participant.

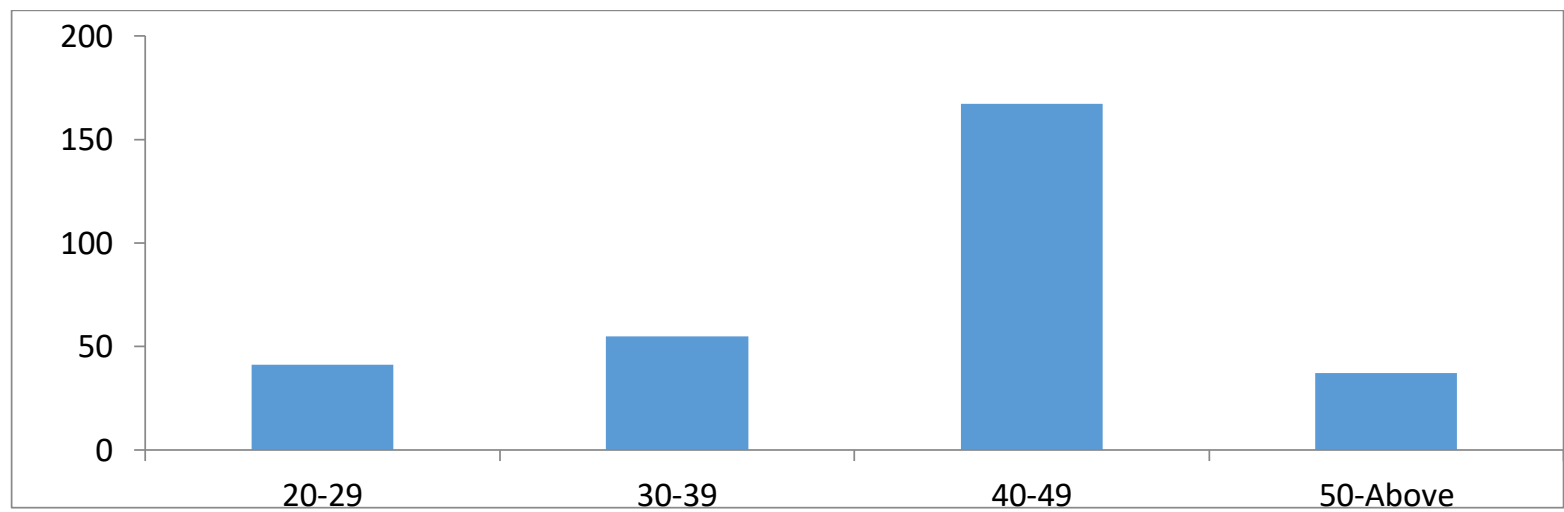

Fig 2:- Shows age distribution of Adamawa State under study Source: field survey, 2020

Age distribution of the respondents for Adamawa state under study is displayed in fig. two, where the greater percentage of respondent are between the ages of 40 and 49 with a large margin followed by the range between 30 and 39 age group of respondent while the aged respondent that is 50 years and above are having the lowest percentage, this is also in line with the study of Loarne-Lemaire et al., (2017) 


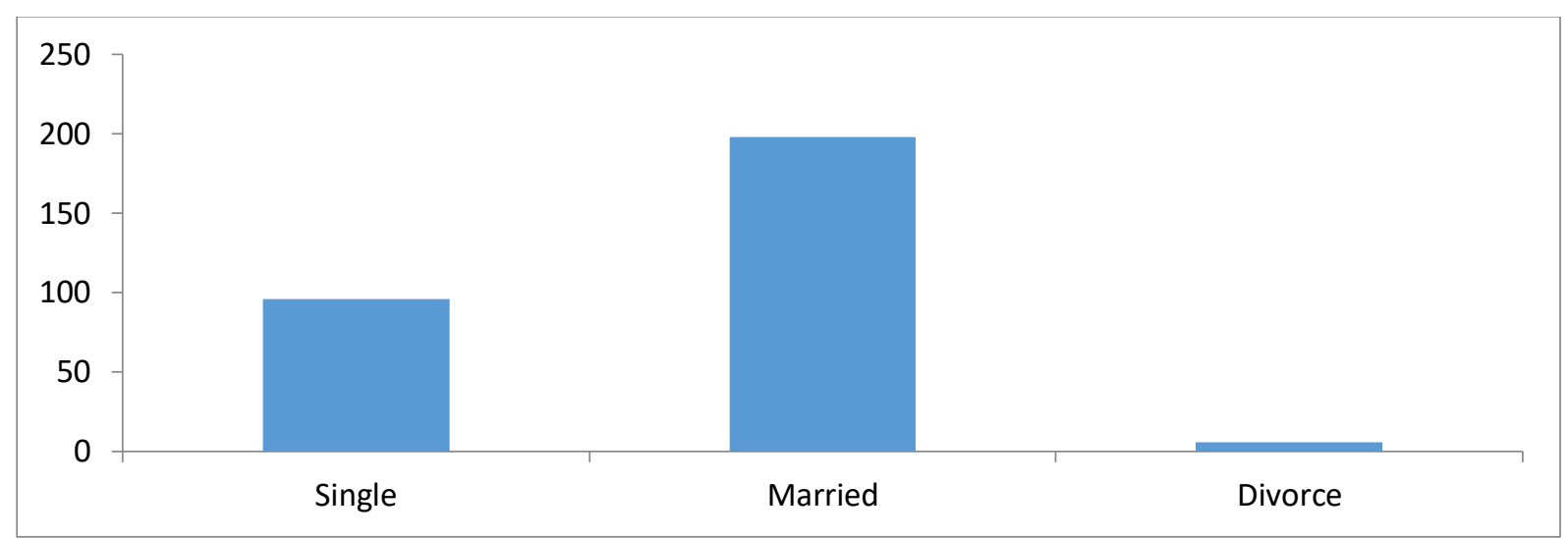

Fig 3:- shows marital status distribution of Adamawa State under study Source: field survey, 2020

Figure 3 displayed the status of respondents in Adamawa state where highest percentage of respondents are married while the single respondents are next, the divorces status of the respondents are having the lowest percentage with negligible number. Referenced from the work of Loarne-Lemaire et al., (2017)

\section{Research Question 1 (Adamawa state)}

The question in table 1 represents the effect of the current industrial policies towards entrepreneurship development and is having 4 items, items 1, 2 and 3 were accepted while item 4 is rejected. Based on the current result generated from the survey quite number of respondent with about 245 responses out of the 300 agreed that current industrial policies create a modern way of setting up a standard business with the highest mean of 1.82 and standard deviation of 0.51 . On the contrary more respondent disagreed with the view that the implementations of industrial policies are reliable, 235 respondent disagreed with that view while 65 respondent agreed the remark here if rejected because of the negative responses, supported by the study of Jones \& Sakong., (2020)

\begin{tabular}{|c|c|c|c|c|c|c|}
\hline S/N & ITEMS & AGREE & DISAGREE & $\bar{X}$ & SD & REMARKS \\
\hline 1 & $\begin{array}{c}\text { Do the current industrial } \\
\text { policies effective to } \\
\text { individual performance as } \\
\text { entrepreneur? }\end{array}$ & 165 & 135 & 1.55 & 0.49 & ACCEPT \\
\hline 2 & $\begin{array}{c}\text { The current industrial } \\
\text { policies create a modern } \\
\text { way of setting up a standard } \\
\text { business }\end{array}$ & 245 & 55 & 1.82 & 0.51 & ACCEPT \\
\hline 3 & $\begin{array}{c}\text { There is greater motivation } \\
\text { towards effectiveness on } \\
\text { the recent industrial } \\
\text { policies }\end{array}$ & 180 & 120 & 1.60 & 0.48 & ACCEPT \\
\hline 4 & $\begin{array}{c}\text { Do you think the } \\
\text { implementations of } \\
\text { industrial policies are } \\
\text { reliable? }\end{array}$ & 65 & 235 & 1.22 & 0.64 \\
\hline
\end{tabular}

Table 1:- The effect of current industrial policies on entrepreneurship

Source: field survey, 2020

$\mathbf{H}^{\mathbf{1}}$ : Based on the findings in question 1 for (Adamawa State) we accept the null hypothesis $\left(\mathrm{H}_{0}\right)$, we therefore conclude that there is a significant effect on the current industrial policies towards entrepreneurship development

\section{Research Question 2 for (Adamawa State)}

From Question 2, table 2 presents 4 items on the perception of both the potential and the current entrepreneurs on the consistencies of government policies towards entrepreneurship development items 1, 2, and 3 were accepted because of the positive response indicated by respondents while item 4 was rejected because the majority of the respondents disagreed with the view in that item which is also in conformity with the study of Jones \& Sakong., (2020) 
ISSN No:-2456-2165

\begin{tabular}{|c|c|c|c|c|c|c|}
\hline S/N & ITEMS & AGREE & DISAGREE & $\bar{X}$ & SD & REMARKS \\
\hline 1 & $\begin{array}{c}\text { Do the current government } \\
\text { policies play a vital role in } \\
\text { encouraging entrepreneurs? }\end{array}$ & 187 & 113 & 1.62 & 0.48 & ACCEPT \\
\hline 2 & $\begin{array}{c}\text { The current government } \\
\text { policies on entrepreneurial } \\
\text { development is timely }\end{array}$ & 250 & 50 & 1.83 & 0.51 & ACCEPT \\
\hline 3 & $\begin{array}{c}\text { Do you think measures taken } \\
\text { by government on industrial } \\
\text { policies are good measures? } \\
\text { The government current } \\
\text { industrial policies helps in } \\
\text { creating more employment in } \\
\text { Nigeria }\end{array}$ & 101 & 199 & 1.34 & 0.57 & RECEPT \\
\hline
\end{tabular}

Table 2:- Evaluate the perception of entrepreneurs on Government policies

Source: field survey, 2020

$\mathbf{H}^{2}$ : Based on the findings in table 2 for (Adamawa State) we accept the null hypothesis $\left(\mathrm{H}_{0}\right)$, we therefore conclude that there is positive perception on the consistencies of government policies towards entrepreneurship development

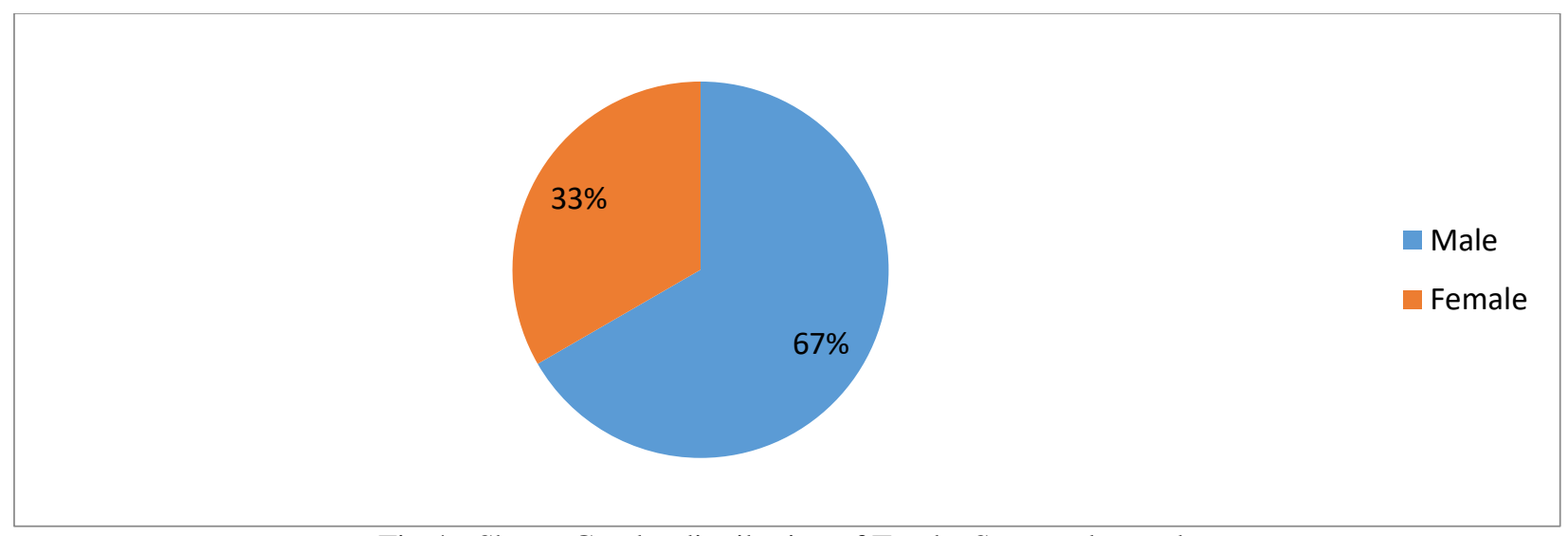

Fig 4:- Shows Gender distribution of Taraba State under study Source: field survey, 2020

From figure 4 the gender distribution in the pie chart for the case of Taraba State respondents shows that majority of the respondents were male with about 67 percent and female having 33 percent, this indicates that more of the prospective and current entrepreneurs were men in Taraba state. This also support the argument of Molina, J., (2020) and Kakouris et al., (2016) that more men are involved in the business than women and there is a need for government to develop a program to encourage female participant.

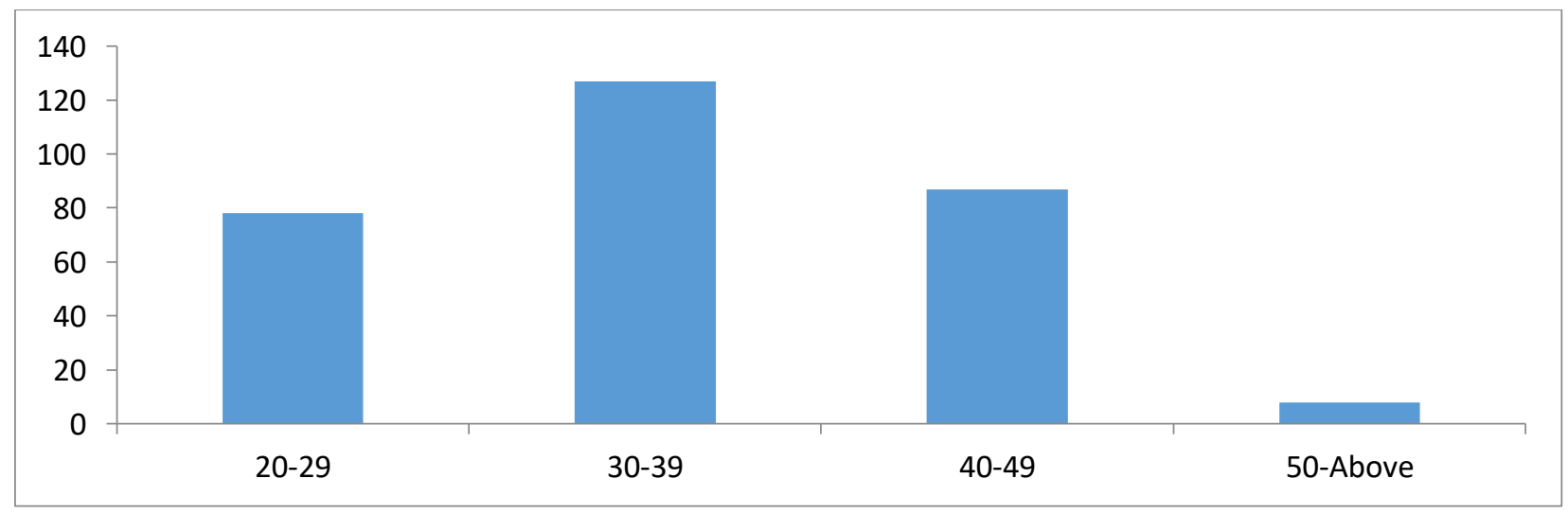

Fig 5:- Shows age distribution of Taraba State under study

Source: field survey, 2020 
Fig. 5 displayed the age distribution of the respondents for Taraba state under study, where the highest percentage of respondents are between the ages of 30 and 39 followed by the range between 40 and 49 age group of respondents while the aged respondents that is 50 years and above are having the lowest percentage, this is also in line with the study of Loarne-Lemaire et al., (2017)

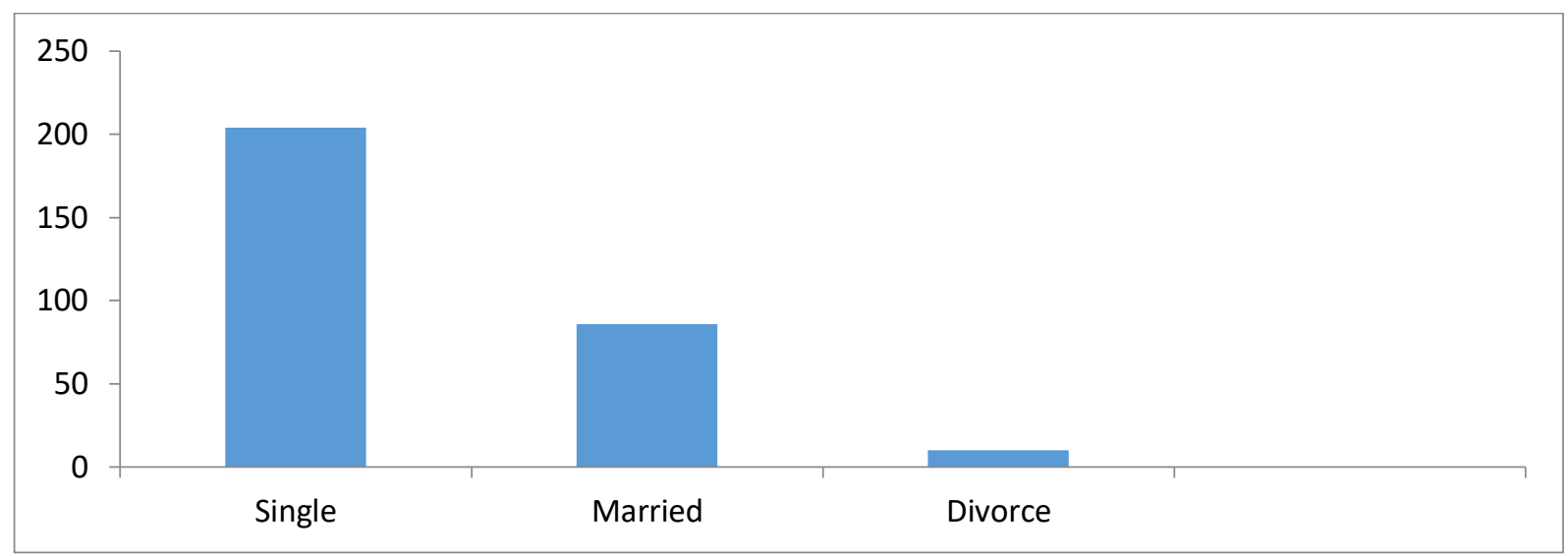

Fig 6:- shows marital status distribution of Taraba State under study Source: field survey, 2020

Figure 6 revealed the status of respondents in Taraba state where majority of the respondents were single while married respondents were having some worth percentage, the divorced status of the respondents were having the lowest percentage with negligible percentage as postulated also by (Loarne-Lemaire et al., 2017; Jakubczak, \& Rawowska., 2013)

\section{Research Question 1 (Taraba State)}

Research question 1 for Taraba state represent the effect of current industrial policies on entrepreneurship displayed in table 3. Table 3. However, has four items and all items were accepted. That is about 256 respondents in item 1 agreed that current industrial policies create a modern way of setting up a standard business with the highest mean of 1.85 and standard deviation of 0.52. while item 3, 1 and 4 have agreed with (230, 197 and 165) with mean and SD of $(1.77,1.66$ and 1.52$)$ and $(0.49,0.48$ and 0.50) respectively, which is in line with the study of Jones \& Sakong., (2020)

\begin{tabular}{|c|c|c|c|c|c|c|}
\hline S/N & ITEMS & AGREE & DISAGREE & $\bar{X}$ & SD & REMRKS \\
\hline 1 & $\begin{array}{c}\text { Do the current industrial } \\
\text { policies effective to } \\
\text { individual performance as } \\
\text { entrepreneur? }\end{array}$ & 197 & 103 & 1.66 & 0.48 & ACCEPT \\
\hline 2 & $\begin{array}{c}\text { The current industrial } \\
\text { policies create a modern } \\
\text { way of setting up a standard } \\
\text { business }\end{array}$ & 256 & 44 & 1.85 & 0.52 \\
\hline 3 & $\begin{array}{c}\text { There is greater motivation } \\
\text { towards effectiveness on the } \\
\text { recent industrial policies }\end{array}$ & 230 & 70 & 1.77 & 0.49 & ACCEPT \\
\hline 4 & $\begin{array}{c}\text { Do you think the } \\
\text { implementations of } \\
\text { industrial policies are } \\
\text { reliable? }\end{array}$ & 165 & 125 & 1.52 & 0.50 \\
\hline
\end{tabular}

Table 3:- The effect of current industrial policies on entrepreneurship

Source: field survey, 2020

$\mathbf{H}^{1}$ : Based on the findings in question 1 for (Taraba State) we accept the null hypothesis $\left(\mathrm{H}_{0}\right)$, we therefore conclude that there is a significant effect on the current industrial policies towards entrepreneurship development in North Eastern Nigeria

\section{Research Question 2 (Taraba State)}

Question 2 for Taraba state under study shows the perceptions of entrepreneurs on the policies of government. Table 2 displayed 4 items and all the items were having a positive responses with majority of the respondents agreed to the questions in all the items, which is also in conformity with the study of Jones \& Sakong., (2020) 
ISSN No:-2456-2165

\begin{tabular}{|c|c|c|c|c|c|c|}
\hline S/N & ITEMS & AGREE & DISAGREE & $\bar{X}$ & SD & REMARKS \\
\hline 1 & $\begin{array}{c}\text { Do the current government } \\
\text { policies play a vital role in } \\
\text { encouraging entrepreneurs? }\end{array}$ & 177 & 123 & 1.59 & 0.48 & ACCEPT \\
\hline 2 & $\begin{array}{c}\text { The current government } \\
\text { policies on entrepreneurial } \\
\text { development is timely }\end{array}$ & 287 & 13 & 1.96 & 0.57 & ACCEPT \\
\hline 3 & $\begin{array}{c}\text { Do you think measures taken } \\
\text { by government on industrial } \\
\text { policies are good measures? } \\
\text { The government current } \\
\text { industrial policies helps a } \\
\text { creating more employment in } \\
\text { Nigeria }\end{array}$ & 246 & 71 & 1.76 & 0.49 & ACCEPT \\
\hline
\end{tabular}

Table 4:- Evaluate the perception of entrepreneurs on Government policies

Source: field survey, 2020

$\mathbf{H}^{2}$ : Based on the findings in table 2 for (Taraba State) we accept the null hypothesis $\left(\mathrm{H}_{0}\right)$, we therefore conclude that there is positive perception on the consistencies of government policies towards entrepreneurship development

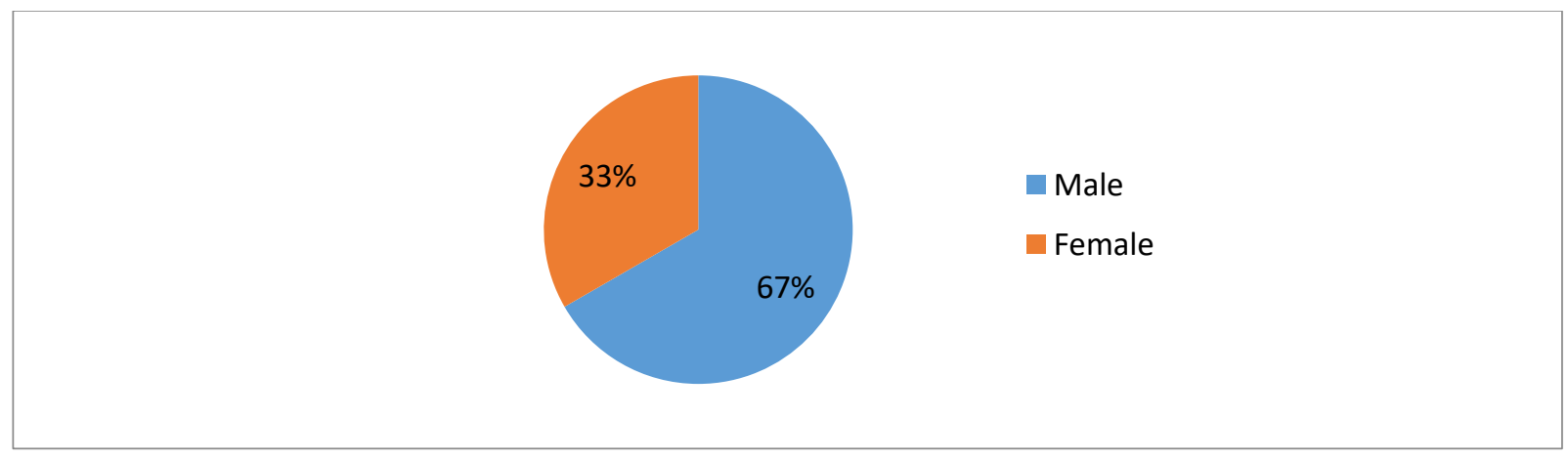

Fig 7:- Shows Gender distribution of Gombe State under study Source: field survey, 2020

Figure 7 shows the gender distribution on the pie chart for Gombe State under study, majority of the respondents were male with about 67 percent and female having 33 percent, this indicates that more of the prospective and current entrepreneurs were men in Taraba state. This also support the argument of Molina, J., (2020) and Kakouris et al., (2016) that more men are involved in the business than women and there is a need for government to develop a program to encourage female participant.

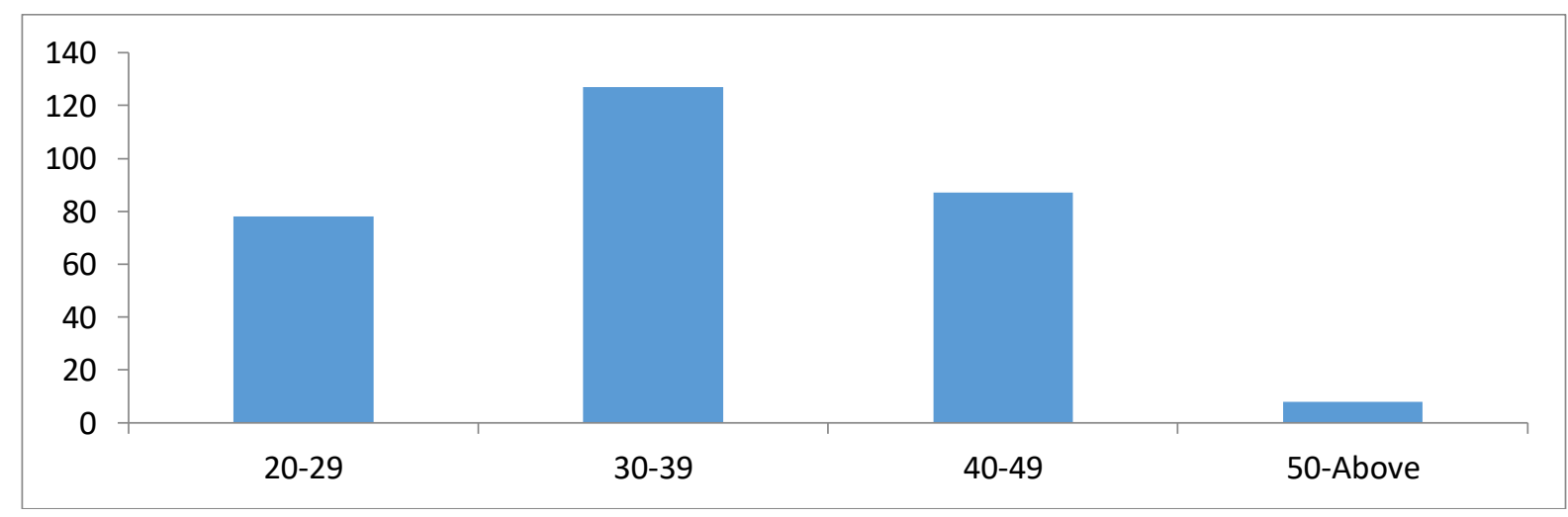

Fig 8:- Shows age distribution of Gombe State under study Source: field survey, 2020

Figure 8 displayed the age distribution of the respondents for Gombe state under study, where the highest percentage of respondents were between the ages of 30 and 39 followed by 40 and 49 age group of respondents while the aged respondents that is 50 years and above are having the lowest percentage, this is also in line with the study of Loarne-Lemaire et al., (2017) 


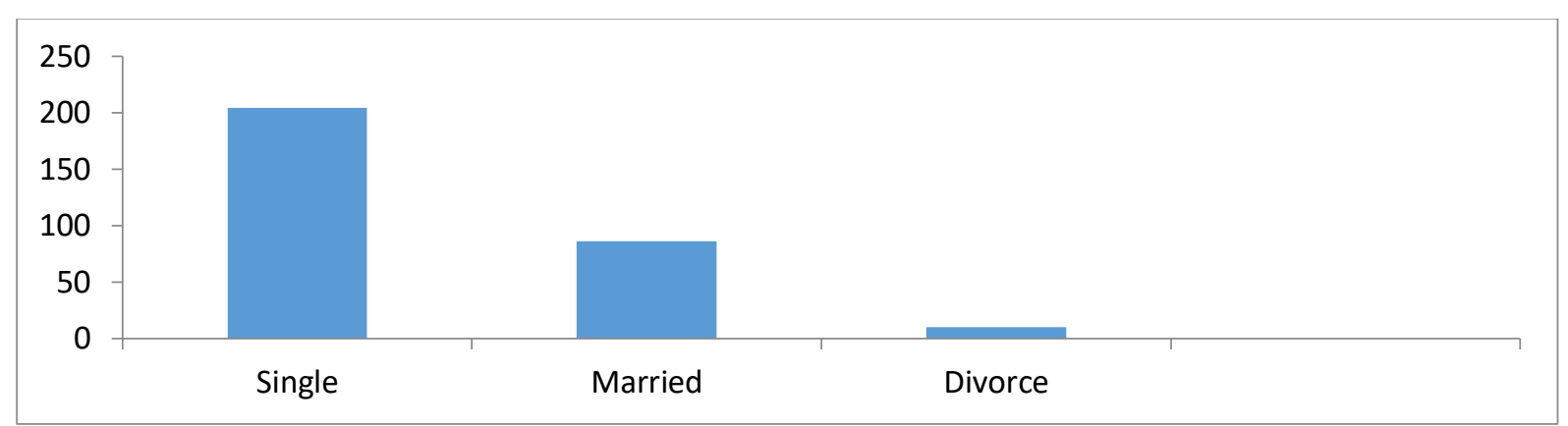

Fig 9:- shows marital status distribution of Gombe State under study Source: field survey, 2020

Figure 9 revealed the status of respondents in Gombe state where majority of the respondents were single while married respondents were having some worth percentage, the divorced status of the respondents were having the lowest percentage with negligible percentage as postulated also by (Loarne-Lemaire et al., 2017; Jakubczak, \& Rawowska., 2013)

\section{Research Question 1(Gombe State)}

Question 1 for Gombe state under study represent the effect of current industrial policies on entrepreneurship as displayed in table 3. Nevertheless, it has 4 items and 3 items were having an affirmative response. So 219 respondents in item 4 disagreed that the implementations of industrial policies are reliable. With the lowest mean of 1.27 and standard deviation (SD) of 0.61. While item 1, 2 and 3 have agreed with (167, 183 and 236) with mean and SD of $(1.56,1.61$ and 1.79) and (0.49, 0.48 and 0.50) respectively, which is in line with the study of Jones \& Sakong., (2020)

\begin{tabular}{|c|c|c|c|c|c|c|}
\hline $\mathbf{S} / \mathbf{N}$ & ITEMS & AGREE & DISAGREE & $\bar{X}$ & SD & REMARKS \\
\hline 1 & $\begin{array}{l}\text { Do the current industrial policies effective to } \\
\text { individual performance as entrepreneur? }\end{array}$ & 167 & 133 & 1.56 & 0.49 & ACCEPT \\
\hline 2 & $\begin{array}{l}\text { The current industrial policies create a modern } \\
\text { way of setting up a standard business }\end{array}$ & 183 & 117 & 1.61 & 0.48 & ACCEPT \\
\hline 3 & $\begin{array}{l}\text { There is greater motivation towards } \\
\text { effectiveness on the recent industrial policies }\end{array}$ & 236 & 64 & 1.79 & 0.50 & ACCEPT \\
\hline 4 & $\begin{array}{l}\text { Do you think the implementations of industrial } \\
\text { policies are reliable? }\end{array}$ & 81 & 219 & 1.27 & 0.61 & REJECTED \\
\hline
\end{tabular}

Table 5:- The effect of current industrial policies on entrepreneurship Source: field survey, 2020

$\mathbf{H}^{\mathbf{1}}$ : Based on the findings in question 1 for (Gombe State) we accept the null hypothesis $\left(\mathrm{H}_{0}\right)$, we therefore conclude that there is a significant effect on the current industrial policies towards entrepreneurship development

\section{Research Question 2 (Gombe State)}

Question 2 for Gombe state under study shows the perceptions of entrepreneurs on the policies of government. Table 6 displayed 4 items and all the items were having a positive responses with majority of the respondents agreeing to the questions in all the items, which is also in conformity with the study of Jones \& Sakong., (2020)

\begin{tabular}{|c|c|c|c|c|c|c|}
\hline $\mathbf{S} / \mathbf{N}$ & ITEMS & AGREE & DISAGREE & $\bar{X}$ & SD & REMARKS \\
\hline 1 & $\begin{array}{l}\text { Do the current government policies play a } \\
\text { vital role in encouraging entrepreneurs? }\end{array}$ & 200 & 100 & 1.67 & 0.48 & ACCEPT \\
\hline 2 & $\begin{array}{l}\text { The current government policies on } \\
\text { entrepreneurial development timely }\end{array}$ & 210 & 90 & 1.70 & 0.48 & ACCEPT \\
\hline 3 & $\begin{array}{l}\text { Do you think measures taken by government } \\
\text { on industrial policies are good measures? }\end{array}$ & 265 & 35 & 1.88 & 0.53 & ACCEPT \\
\hline 4 & $\begin{array}{l}\text { The government current industrial policies } \\
\text { helps a creating more employment in Nigeria }\end{array}$ & 220 & 80 & 1.73 & 0.48 & ACCEPT \\
\hline
\end{tabular}

Table 6:- Evaluate the perception of entrepreneurs on Government policies

Source: field survey, 2020 
$\mathbf{H}^{\mathbf{2}}$ : Based on the findings in table 2 for (Gombe State) we accept the null hypothesis $\left(\mathrm{H}_{0}\right)$, we therefore conclude that there is positive perception on the consistencies of government policies towards entrepreneurship development

\section{CONCLUSION AND POLICY IMPLICATION}

It is clearly shown that there is growing interest on how government industrial policy can aid the development of entrepreneurship in any given economy. Several debate with growing acceptance that industrial policy on entrepreneurship support the economic and social transformation. In contrast, some argue that certain policy measure cannot be involve in promoting the innovation. The primary objectives of this current study is to assess the nexus between industrial policies and entrepreneurial development in North Eastern Region of Nigeria and several specific objectives were also drawn. Consequently, two hypotheses were constructed with two with dimensions of questions, chi-square method of analysis was employed in the study, others include; percentage, pie charts, bar charts and tables were used in presenting the results generated from the data. The findings of this research work reveals that there is a significant effect on the current industrial policies towards entrepreneurship development and also a positive perception on the consistencies of government policies towards entrepreneurship development.

The policy implication and recommendations of the study suggest that the implementation of the industrial policies should be more reliable and implemented to cover the required beneficiaries that is the prospective and the current entrepreneurs. In addition, more effort need to be put in place in order in developing the policy for more employment generation and gender sensitive program on women entrepreneurship need also to be considered. Finally, the ministry of commerce and industry and central banks should corroborates to enhance proper management of entrepreneurial program towards achieving socioeconomic development and providing more avenue for job creation

\section{REFERENCES}

[1]. Alola, A. A. (2019). The trilemma of trade, monetary and immigration policies in the United States: Accounting for environmental sustainability. Science of The Total Environment, 658, 260-267.

[2]. Adenipekun, M. T. (2013). Sustainable rural infrastructural development in Nigeria within the context of Vision 20: 2020. International Journal of Development and ustainability, 2(1), 254-269.

[3]. Arcand, J. L., Berkes, E., \& Panizza, U. (2015). Too much finance? Journal of Economic Growth, 20(2), 105-148.

[4]. Chienwattanasook, K., \& Jermsittiparsert, K. (2019). Impact of entrepreneur education on entrepreneurial self-employment: a study from Thailand. Polish Journal of Management Studies, 19.
[5]. Draper, T. (2017). American business and public policy: The politics of foreign trade. Routledge.

[6]. Jakubczak, J., \& Rawowska, A. (2013). The role of education and culture in the development of youth entrepreneurship in European Union. In Management, Knowledge and Learning Internafional Conference (pp. 997-1003).

[7]. Jones, L. P., \& Sakong, I. (2020). Government, business, and entrepreneurship in economic development: The Korean case. Brill.

[8]. Kakouris, A., Dermatis, Z., \& Liargovas, P. (2016). Educating potential entrepreneurs under the perspective of Europe 2020 plan. Business \& Entrepreneurship Journal, 5(1), 7-24.

[9]. Lucchese, M., Nascia, L., \& Pianta, M. (2016). Industrial policy and technology in Italy. Economiae politica industriale, 43(3), 233-260.

[10]. Loarne-Lemaire, S. L., Maalaoui, A., \& Dana, L. P. (2017). Social entrepreneurship, age and gender: toward a model of social involvement in entrepreneurship. International Journal of Entrepreneurship and Small Business, 31(3), 363-381.

[11]. Molina, J. A. (2020). Family and entrepreneurship: New empirical and theoretical results. (2020) 1-3

[12]. Nasiripoor, A. A. (2013). Individual Features Affecting Organizational Entrepreneurship Development in Iranian Public Hospitals. Journal of Rafsanjan University of Medical Sciences, 12(9), 681694.

[13]. Mary, O. E., Enyinna, U. K., \& Ukpai, K. A. (2015). The effect of policy measures on entrepreneurship development analysis of Nigeria's experience. Ile, 7(19).

[14]. Ndofirepi, T. M. (2016). The impact of technological creativity and entrepreneurship education on the entrepreneurship intentions of students at particular tertiary institutions in Zimbabwe and South Africa (Doctoral dissertation, Bloemfontein: Central University of Technology, Free State).

[15]. Onukwuli ${ }^{1}$, A. G., D, U. G. A. P., \& Onwuka, E. M. (2014). Challenges of Small Scale Industries in Sustainable Development in Nigeria.

[16]. Pradhan, R. P., Arvin, M. B., Nair, M., \& Bennett, S. E. (2020). The dynamics among entrepreneurship, innovation, and economic growth in the Eurozone countries. Journal of Policy Modeling.

[17]. Schwab, A., \& Zhang, Z. (2019). A new methodological frontier in entrepreneurship research: Big data studies.

[18]. Yaghmaei, O., \& Ghasemi, I. (2015). Effects of influential factors on entrepreneurial intention of postgraduate students in Malaysia. International Letters of Social and Humanistic Sciences, 51, 115124. 